\title{
The Implementation of Learner Centred Approach and Reposition of Education in Public Secondary Schools in Nyamagana District, Mwanza-Tanzania
}

\author{
Gloria Mgyabuso, Demetria Gerold Mkulu
}

Department of Educational Foundation, St. Augustine University of Tanzania, Mwanza, Tanzania Email: glorymugyabuso@gmail.com; mkuludemetria@gmail.com

Received: 30 Nov 2021; Received in revised form: 15 Jan 2022; Accepted: 30 Jan 2022

C2022 The Author(s). Published by TheShillonga. This is an open access article under the CC BY license (https://creativecommons.org/licenses/by/4.0/)

\begin{abstract}
Learner Centred Approach has been emphasized in Tanzania for several years since 1995. The country made reforms on various education policies and programs to ensure students are trained through LCA to realize national educational objectives. This study, therefore, sought to assess the implementation of LCA in public secondary schools. The study was guided by four specific objectives. Also, it was anchored on constructivism learning theory developed in 1929 and adopted in the field of education. The researcher employed a mixed research approach and a convergent parallel research design to collect data from the field. The researcher involved teachers, school heads, students, WEOs, and DEO. A sample size of 165 informants was employed to get data in quantitative and qualitative terms. Quantitative data were analyzed through SPSS version 20, while qualitative data were analyzed through the content analysis method by coding, categories, and themes. Validity and reliability of the quantitative instruments were checked to obtain 0.80 coefficients which indicated that the instruments were valid and reliable while for qualitative instruments validity and reliability were tested through triangulation. The findings demonstrated that LCA plays a significant role in developing students' lifelong learning skills. It develops creativity, critical thinking, problem-solving skills, and innovation. Notwithstanding, the study found that teachers and students had a positive perception of the application of LCA, however its implementation in public secondary schools is minimal due to environmental challenges which lead to poor academic performance in students.
\end{abstract}

Keywords - Learner Centred Approach, Implementation, Reposition, Public Secondary Schools.

I. INTRODUCTIONAND BACKGROUND TO THE STUDY

Teaching methods determine the quality of education provided to the learners in schools within the country. Tanzania has been struggling to ensure teachers are in line with Learner Centred Approach as a new teaching paradigm to promote the performance of students in secondary schools. Through this teaching, approach teachers have to plan and design instructions to boost the performance of students in schools. Despite all the efforts, still, the performance of students in some schools is not pleasing. It is questionable how teachers adopted and perceive Learner Centred Approach to achieve intended objectives
Public secondary schools have been affected by poor results in their Certificate of Ordinary secondary education final examinations. The country has been struggling to improve quality education by emphasizing the application of Learner Centred Approach in its educational institutions. To achieve this objective Tanzania has made reforms of various educational policies, documents, and programs to stress the application of LCA. According to URT (1999) Education and Training Policy (ETP) of 1995 identified indicators such as participation, involvement, creativity, curiosity, discovery, integrity, confidence, and self-development as important elements to be elicited in learners. Therefore, the policy emphasized that these elements could not be achieved in absence of a student-centered approach in schools. Likewise, 
the need for Learner Centred Approach has also been reflected from various national documents such as Tanzania Development Vision 2025, Education Sector Development Programme (ESDP) of 2007/2008 to 2016/2017, and ESDP $2016 / 2017$ to $2020 / 2021$ as well as Sustainable Development Goals of 2017/2030. All these documents emphasize the need to promote quality education in the country and thus LCA becomes inevitable.

\section{STATEMENT OF THE PROBLEM}

Learner Centred Approach has been advocated in student learning in Tanzania for a quite long time. Poor performance in secondary schools has been evident in the poor use of LCA in education institutions. In the Nyamagana district, poor academic performance has been witnessed in some public secondary schools due to. For example, according to NECTA results 2020, Nyakabungo secondary school, students who got division 4 to 0 were 60 percent. In Mirongo secondary school they were 55.8 percent and in Ole Njoolay secondary school, 75.6 percent scored division 4 to 0 . Similarly, the graduatorsdo not have the creativity, selfconfidence, and problem-solving skills to deal with life challenges. Various educational policies, documents, and programs have pointed to the importance of LCA to student learning. For example, the curriculum for ordinary level secondary education in Tanzania showed that learning should be rooted in the concept of constructivism whereby students get opportunities to interact with the environment through well-organized tasks to build Multiple Intelligences (TIE, 2013). Likewise, the need for Learner Centred Approach has also been shown in various national documents such as Tanzania Development Vision 2025, Education Sector Development Programme (ESDP) of 2007/2008 to 2016/2017, and ESDP 2016/2017 to 2020/2021 as well as Sustainable Development Goals of 2017/2030. These documents emphasize the need to promote quality education by focusingon LCA as an important learning approach in schools. Also, URT (2017) noted that amidst laudable achievements in expanding access to secondary education in Tanzania poor learning outcomes and poor lifelong skills among graduates are still evident. The situation indicated there are differing perceptions on the implementation of Learner Centred Approach among teachers in schools. It is in this regard; the current study intends to examine the contributions of LCA on repositioning education in public secondary schools in Nyamagana district in Mwanza-Tanzania.

\section{OBJECTIVES OF THE STUDY}

The researcher used the following objectives to guide the study.

i. To determine the contributions of LCA on reposition of education in public secondary schools in Nyamagana District

ii. To ascertain teachers' perceptions on the use of LCA and reposition of education in public secondary schools in Nyamagana District

\section{SIGNIFICANCE OF THE STUDY}

The findings of this study are beneficial to many education stakeholders such as curriculum planners, policymakers, teachers, and students. The curriculum planners would benefit from the study as it created knowledge concerning planning and implementation of the curriculum. Therefore, the planners can develop the effective methodology required for the learners to develop intended skills. Also, they would be able to prescribe LCA as the best methodology in developing lifelong learning skills for the learners and recommend the possible solution to the challenges combating Learner Centred Approach in secondary schools. Also, for the policymakers, the findings from this study can assist them to create an effective education policy to prepare learners with creativity, curiosity, discovery, and selfconfidence to participate in their self-development and society at large. Also, the policymakers would be in a good position for creating a conducive learning climate that allows the smooth application of LCA. Moreover, for the teachers, this study highlights to the teachers the importance of Learner Centred Approach to the students in secondary schools. Thus, the study helps teachers to invent different strategies for applying LCA in

teaching to develop students' life skills. This study would also be helpful to the learners to visualize knowledge by creating awareness on the importance of LCA to develop lifelong learning skills. Likewise, learners would raise the sense of creativity and develop a sense of participation in various matters, self-confidence, and self-developments. The study would help learners to be knowledgeable, skilled, confident, problem solvers in different matters.

\section{LITERATURE REVIEW}

The empirical literature review is based on the research objectives of the current study. In this section, the researcher conducted a critical review of several articles from scholarly works based on the study objectives. The objectives included 
the contribution of LCA on repositioning education in secondary schools and the Perceptions of teachers on the implementation of LCA in public secondary schools. Also, in the review, the study recognized some gaps which raised the interest of the current study.

\subsection{Contribution of Learner Centred Approach on Reposition Education}

In this section, the researcher reviewed a variety of scholarly works to seek the contribution of LCA on repositioning education in secondary schools worldwide. In Europe, Go, Krawczak, and Pawe (2018) conducted a study on empowering teachers for a student-centered approach in European Countries. The study employed quantitative methods in the collection and analysis of data. Questionnaires were used to get data in a cross-section survey. The researcher found that the motivation of students, developing partnerships between teachers and students, and students to be more focused on their learning are the consequences of LCA. Similarly, Risk, Self, McKean, and McKean, (2014) added that the learner-centered Approach increased students' level of students' excitement in learning, raise achievement students 'prove students confidence levels. Thus, its implementation on a learner-centered approach makes students be part and parcel of their learning and participate actively in educational activities for their selfdevelopments. It enhances students' cooperation in various matters.

Also, Keiler (2018) carried out a study on teachers' roles and identities in student-centered classrooms in the USA. The researcher used qualitative methods in the collection and analysis of data. The descriptive explanatory design was employed in the process of data collection. The study revealed that LCA helped teachers to develop shared responsibility for students learning with student leaders. This result entails that LCA contributes to students learning by equipping leadership skills and increasing accountability and commitment in students. Likewise, In Turkey, Zek (2014) asserts that the student-centered method helped to improve student-teacher cognitive skills develop self-confidence autonomy, and make the learning process meaningful to university students. However, this was focusing on University students it is also meaningful to students in secondary schools where the foundation of self-confidence and cognitive skills are made. From this point of view, it entails that LCA should be emphasized in secondary schools to create independent learning skills in students. Ching, Lawrence, and Abdullah, (2019) in Malaysia argue that the student-centered approach creates a platform or an opportunity for the learners to be more independent in decision making and encourages learners to be more responsible.

In the same vein, Toole (2015) investigated student-centered teaching in initial teacher education in Ireland. The study adopted quantitative methods in the data collection process. Semi-structured questionnaires were employed as an instrument of data collection from undergraduate teachers. The results showed that LCA offers a powerful vehicle for educators to work within neo-liberal systems without being of the system and increases accountability of students. LCA plays an important role in shaping students for lifelong learning skills through accountability and practice. Cabe (2015) in Dundalk Institute of Technology in Ireland also found that the student-centered approach enables the creation of a more autonomous learning environment and helped students to make meaningful content for their society and economy. Thus, this raises the need to adapt LCA in the teaching of secondary school students.

In Iran, Asoodeh and Zarepour, (2012) conducted a study on the impact of student-centered learning on academic achievement and social skills. The study adopted quantitative methods in the data collection and analysis process. Questionnaires and observation checklists were used as instruments of data collection from the participants' settings. The results showed LCA provides an opportunity for social acceptance, self-confidence and improves the mental ability of the learners. LCA promotes critical thinking in students and increases self-commitment in academic matters and social activities in general. In the same line, Singh (2011) in India maintains that the learner-centered approach boosts student interest, increases commitment, confidence, reasoning, innovative ability, better understanding, and problem-solving skills. Therefore, LCA is an important approach in developing students' capacity and critical minds while in school.

In addition, Cain (2020) carried out a study on Understanding the use of learner-centered teaching strategies by secondary education. The researcher used qualitative methods in data collection and analysis. The interview protocol was employed in the collection of data from the participants. The researcher showed that learner-centered teaching strategies increase student engagement, improve academic achievements and encourage positive social change. Thus, from the point of view of those literary reviews, a researcher perceives that LCA promotes lifelong learning in students through active participation in the 
learning process. Learning by doing helps students to have a good memory and hence raises their performance in schools.

Businge and Kakongoro (n.d.) carried out a study on a teacher-centered delivery approach in Uganda's secondary school's education and empowering learners with higherorder skills. The study employed mixed methods in the collection and analysis of data. The researcher used questionnaires, focused group discussion (FGD) interview guide in collecting data from the participants. The result showed that the student-centered approach equips learners with higher-order skills and leads to effective teaching and learning skills.

In Tanzania, Kamugisha, (2019) conducted a study on the use of LCA and materials in teaching and learning social science subjects in secondary schools. The study involved both qualitative and quantitative methods in the collection and analysis of data. The researcher used documentary review, observation, and questionnaires to get data from the field. The study indicated that experimental school motivated students learning and increase performance in secondary schools. Therefore, a researcher concludes that LCA should be emphasized in school to increase students' motivation to participate fully in the learning to boost their academic performance.

\subsection{Perception of Teachers on the Application of Learner-Centred Approach}

In this part, the researcher conducted a literature review of various articles to seek the perceptions of teachers on the use of LCA to reposition education in public secondary schools. In Malaysia, Kok and Lim (2016) made an investigation on teacher views of the student-centered learning approach. This study applied purely qualitative methods in the collection and analysis of data. The researcher employed interviews and semi-structured questionnaires in a qualitative design to get data from the participants. The result indicated that teachers viewed LCA as an important learning approach in which students engaged in the learning process, be aware of their responsibilities, create a sense of autonomy in learning and teachers can learn from their experience. In Bangladesh, Jony (2016) found that teachers perceive student-centered instructions as important to improve the ability of students to learn the content and prepare them for class. These findings indicate that teachers perceive LCA positively. However, in a real sense, the majority of teachers seem not to apply it in the teaching and learning process.

Also, Benlahcene, Lashari, and Shehzad, (2020) investigated the perception of students using a student-centered learning approach in Malaysian public universities. The study applied qualitative methods in the data collection and analysis process. Furthermore, the researcher used observation and interview questions to get data from the participants. The finding indicated that students' explicit positive viewpoints about student-centered learning. However, students perceive LCA positively teachers in public secondary schools prefer using a teacher-centered approach instructing students which does not offer students the opportunity to engage in learning actively. Garrett (2008) argues that teachers in New Jersey think about the relationship between instruction and classroom management but do not use student-centered management to support their student-centered instructions. Therefore, however teachers and students have positive attitudes towards LCA, the school practices are minimal.

Moreover, in Pakistan, Thomas (2013) carried out a study on teachers' beliefs about classroom teaching approaches. The researcher used quantitative methods in the collection and analysis of data. Notwithstanding, the study used a crosssectional survey design in the data collection process. The researcher employed questionnaires to collect data from participants. The findings indicated that teachers in Pakistan are not well equipped with the knowledge and skills required to utilize LCA in class and therefore lack of pedagogical content knowledge and beliefs in some teaching methods inhibits them from student-centered teaching. In the same line, Jabbour (2013) in Lebanon added that schools require the adaptation of the traditional lecture approach of education through which physical, human and financial resources can be controlled. Thus, teachers' beliefs in some teaching methods prohibit them to apply LCA resulting in poor learning outcomes in students of secondary schools

In Lesotho, Matsau (2007) conducted a study on the learnercentered approach in language teaching. The researcher used mixed research methods in collecting and analyzing data. The study employed questionnaires, observation, and focus group discussions to get data from the field. The study showed that teachers and learners considered working alone (learner-centered) to be important in building confidence and independence skills. Hence teachers believed in teachercentered to have independence for classroom control while students considered LCA as important to build their confidence and problem-solving skills.

Notwithstanding, In South Africa,Ec (2020) investigated student teachers' perceptions of learner-centered challenges regarding learner-centered teaching. The study employed qualitative methods in collecting and analyzing data. The interview protocol was used to get data from the participants. 
The result indicated that student teachers have a limited understanding of learner-centered teaching. Similarly, Nyimbili, Namuyamba, and Chakanika, (2018) in Zambia found that teachers were not interested in teaching using learner-centered techniques hence they use a limited number of teaching activities in the teaching of students in secondary schools. Teachers' lack of interest in the application of learner-centered teaching prohibits lifelong learning in students. Therefore, the teachers should be encouraged and motivated to use LCA in teaching students to develop lifelong learning skills in students.

In Tanzania, Salema (2015) assessed the attitudes of teachers and students towards learner-centered pedagogy in secondary schools in the Kilimanjaro region. The study used mixed research methods in the collection and analysis of data. The researcher employed questionnaires and in-depth interviews to collect data from the participants. The study indicated that teachers in public secondary schools have low attitudes towards learner-centeredapproaches compared to private secondary school teachers. In the same line (Ngailo, 2019) in Mbeya Tanzania found that teachers in public secondary schools do not conduct field trips due to lack of funds and the introduction of a new educational curricular 2015 of fee-free education. The findings implied that teachers do not believe in the use of LCA for classroom management and therefore advocated the use of a teachercentered approach that cannot aid students to develop lifelong learning skills and good performance.

The researcher noted some gaps in previous literature such as methodology, context, and contents gaps. Some reviewed literature indicated that many countries in the world have adopted LCA in their education system so that learners achieved quality education. European and Asian countries seem to have many studies on LCA compared to African countries, such as Go (2018), Risk and Mackean (2018), Keiler (2018), Zeki (2014), Toole (2015), and Jony (2016) among others. African countries, especially Tanzania, had inadequate studies over the implementation of LCA to reposition education. Also, some of the previous studies have shown that researchers employed single methods for the data collection process in which findings could not be generalized. These include Thomas (2013), Kok and Lim (2016), Jony (2016), Cain (2020) Jabbour (2013), Elize (2020), Mkimbili (2018), Mpho (2016), Go, Krawczack\&Pawe (2018), Bosser, Lundin \&Lindahl (2015), Gelsli (2009), Zhao, Ah and Mock (2019), Kumar (2016), Idd and Chimwanga (2017), Mtitu (2014) and others. The current study employed mixed research methods to get credible information on the implementation of LCA in secondary schools.

\section{RESEARCH METHODOLOGY}

This study was mixed research whereby both qualitative and quantitative methods were adopted to get data from participants in a convergent parallel design. Creswell and Plano (2007) noted that the use of quantitative and qualitative approaches in combination provides a better understanding of the research problem. Also, purposive and non-purposive sampling techniques were employed to get 165 informants from teachers, heads of schools DEO, WEOs, and students to provide data on the implementation of LCA in secondary schools. Furthermore, questionnaires, interview guides, and observation checklists were used as instruments of data collection in the field. During the process of data collection validity and reliability of the instruments were checked to seek if they could measure the required content. After the data collection process, the analysis was done through the aid of Statistical Package for Social Science (SPSS) for quantitative data while for qualitative data content analysis method was applied. Therefore, for qualitative data, it was assigned into categories, themes, integration, and summarization then interpreted in combination. Finally, the researcher observed ethical standards for conducting educational research by acknowledging sources of materials, privacy, and safety of participants.

\section{RESULT AND DISCUSSION}

In this objective, the researcher wanted to examine the extent to which Learner Centred Approach contributes to repositioning education in public secondary schools in Nyamagana District. Participants involved included teachers, students, heads of schools, Ward Education Officers (WEOs), and District Education Officer (DEO) for secondary schools in the Nyamagana district. Teachers and students were given questionnaires to fill in while DEO, WEOs, and heads of schools were interviewed to provide data.

\subsection{Contribution of Learner Centred Approach on Repositioning Education}

Teachers were asked if the Learner Centred Approach in school promoted lifelong learning skills in students. The results showed that 83.9 percent replied "Yes" while 
16.1 percent of the participants said "No" which means it did not promote lifelong learning in students. Similarly, students were asked similar questions and the data indicated that 86.5 percent replied "Yes" while 13.5 percent said "No" which means it did not promote lifelong learning skills. The findings entail that majority of the participants agreed that the application of LCA in teaching and learning develops life learning skills in students however, in a real sense majority of teachers in the selected schools do not apply it. For example, through observation, the researcher recognized that teachers preferred teaching through the lecturing method to other methods of teaching. In line with the findings by Thomas (2013) that teachers are not well equipped with the knowledge and skills required to utilize LCA in class and Table 7.1 Participants Responses on the Importance of LCA (Teachers $n=62 ;$ Students $n=96)$

\begin{tabular}{lcccc}
\hline Teachers Responses & \multicolumn{2}{c}{ Teachers } & \multicolumn{2}{c}{ Students } \\
& Frequency & Percentage & Frequency & Percentage \\
\hline Independent Learning & 14 & 22.6 & 10 & 10.4 \\
Critical thinking & 22 & 35.5 & 21 & 21.9 \\
Problem-Solving skills & 12 & 19.4 & 7 & 7.3 \\
Career Choices & 8 & 12.9 & 0 & 0 \\
Select Combination & 6 & 9.7 & 0 & 0 \\
Promotes leadership skills & 0 & 0 & 17 & 17.7 \\
Enhances Cooperation & 0 & 0 & 8 & 8.3 \\
\hline
\end{tabular}

Source: Field Data September 2021

\section{Developing Critical Thinking}

Table 7.1 shows that 35.5 percent of the participants argued that LCA develops critical thinking in students. Just like teachers, students were asked a similar question and the result showed that 56.3 percent entailed LCA develops creativity in students. The findings imply that Learner Centred Approach plays a significant role in developing students' competence in the learning process. It develops students thinking capacity and widens their knowledge in various issues about their daily life. Also, during the interview, an interviewee asserted that;

Focusing a learner as the center of learning develops his/ her ability to think critically about what is learned. The student learns curiously and discovers various issues about given contents. The student goes beyond the content and thus comes with therefore lack of pedagogical content knowledge and beliefs in some teaching methods inhibits them from adopting constructivist learning. On the other hand, 13.5 percent of the participants denied it because they do not use LCA in the teaching and learning process in public secondary schools which led to the poor academic performance of students in Nyamagana District.

Moreover, teachers were asked to explain how LCA promotes lifelong learning skills in students in Nyamagana District. Participants said that Learner Centred Approach develops creativity, critical thinking, problems solving skills, career choices, selection of combination, and promotes independent learning in students as indicated in Figure 4.1. 
students in the selected public secondary schools in the Nyamagana District.

\section{Independent Learning}

The teaching which focused on the learner as a center of learning develops independent learning in students. In responding to the question of how LCA promotes lifelong learning skills in students, table 7.1 indicated that 22.6 percent of the participants argued that it made students learn independently. Also, when students were asked a similar question, 10.4 percent showed that it promoted independent learning. The findings entailed that participants viewed LCA as an important teaching and learning strategy that could promote students' accountability and commitment to learning. The findings concurred with Risk, Self \& McKean (2014) who reported that the learner-centered Approach increased students' level of self-efficacy, students' excitement in learning, raise achievement in learning. Despite the role played by LCA to empower students learning ability, in the Nyamagana district few teachers adopted Learner-Centered Approach to instruct students in the selected secondary schools.

In the same vein, in the interview, some respondents elicited Learner-Centered Approach as an important teaching strategy that raised students' desires in learning. An interviewee responded that:

The learner-Centered Approach is a crucial teaching method that can drive students from teacher-dependent to self-learning. When a student participates in his/ her learning will not forget what she/ he learned. Also, the method motivates a student to be curious and learn more and more independently. This type of learning develops a curiosity in students and confidence in learning (Interviewee, 5 September 2021).

This response was also in line with constructivism learning theory which posits LCA results to active learners who can create their knowledge (Hariss, Jessica \&Spina, 2013). Similarly, in the conceptual framework, it is indicated that employing learner-centered techniques such as discussion, group projects and brainstorms leads to lifelong learning skills and self-directed learning. Thus, teachers in the selected secondary schools have to adopt LCA to stimulate independent learning in students.

\section{Develops problem-solving skills}

Also, in responding to the question on how LCA promotes lifelong learning Table 7.1 indicates that 19.4 percent of the respondents said that it developed problem-solving skills in students. Just like teachers, also respondents from students, 7.1 percent argued similarly to their teachers' responses. Respondents viewed LCA as a crucial strategy in teaching and learning that empowers students in critical thinking and dealing with their prevailing challenges.

Although both teachers and students in the selected schools found LCA as an important learning strategy, it was found that teachers in the selected schools did not apply it in the teaching and learning process. For example, through observation, it was found that teaching and learning resources were inadequate and some teachers did not have awareness of appropriate teaching approaches that could develop students' knowledge to solve their prevailing challenges.

Similarly, in South Africa, Manqele (2017) maintained that rural schools failed to adopt and implement LCA due to lack of relevant resources, poor quality teachers, insufficient and inappropriate teacher support programs. In the selected schools, the researcher found out that teaching was mainly based on memorization of facts than the creation of knowledge. The findings were contrary to the principle of constructivism learning theory which is based on the assumption that learning emphasis is not on memorizing facts and reproducing knowledge but rather using knowledge and transforming it. Thus, it can be concluded that there is a need to retrain teachers through seminars and workshops to help them adopt LCA effectively in public secondary schools in the Nyamagana district.

\section{Selection of combinations for further studies}

Table 7.1 indicates that 9.7 percent of the participants argued that LCA enabled students to select a combination for further studies. The findings entail that learning which focused on constructivist activities motivates students to specify their favorite subjects. The finding is also in line with constructivism learning theory as stated by Gunduz and Hursen (2015) that in the classroom constructivist activities empower the learners to gain access to their experiences and beliefs. Moreover, Risk, Self, McKean, and McKean (2014) added that the learner-centered Approach increased students' level of self-efficacy, students' excitement in learning, raise achievement, and improved students' confidence levels. Thus, LCA has a significant impact on students; it develops as their' awareness of what he/she can learn, throughouttheir life. Also, cost-increased learning activities increase 
students' learning efficiency and thus ability to select properly desired subjects. In Nyamagana district, the findings entailed LCA was not mostly applied because very few participants (9.7) percent were argued it helped students to select the combination compared to other attributes. The results addressed that there was a need to emphasize the application of LCA in the selected schools to help students in the selection of their favorite subjects.

\section{Career choices}

Just like other attributes table 7.1 showed that 12.9 percent said LCA helped students to select their career. The result was similar to Lawrence and Abdullah (2019) in Malaysia who found that the student-centered approach created a platform or an opportunity for the learners to be more independent in decision making and encourage learners to be more responsible. In the Nyamagana district, it was found that in schools where teachers advocated LCA in the teaching and learning process students were eager to perform certain careers after their studies. In responding to the interview question an interviewee asserted that:

Students are motivated to do what they learn by practice. LCA widen up their knowledge of different things. Also, it helps students to make choices of what to do in life (Interviewee, 4 September 2021).

The findings also concurred with Cabe (2015) in Ireland who found that the student-centered approach enables the creation of a more autonomous learning environment and helped students to make meaningful content for their society and economy. Teachers need to emphasize the use of LCA in the selected public schools in the Nyamagana district to help students to develop their career choices.

Likewise, participants from students were asked to explain how LCA promotes lifelong learning skills. Table 7.1 shows that students develop creativity by 34.4 percent, problemsolving skills by 7.3 percent, cooperation by 8.3 , critical thinking by 21.9 percent, independent learning by 10.4 percent, and promoting leadership skills by 17.7 percent.

\section{Encourages cooperation}

In responding to the question asked on LCA, table 7.1 showed that 8.3 percent asserted that students develop cooperation. The findings entail that learning by doing made students work cooperatively as they practice the learning activities. In the same vein, the conceptual framework showed that LCA required the use of discussions, field trips, brainstorms, and cooperative learning techniques such as gallery walk to help the student to think critically on various issues as well as problem-solving skills. These learning techniques help students develop friendships and work cooperatively in solving their prevailing challenges.

\section{Develops leadership skills}

Table 7.1 indicated that 17.7 percent of students investigated, demonstrated that LCA help to develop leadership skills. The finding showed that participants viewed LCA as an important teaching method to help students develop leadership skills. LCA encourages group discussions and group works in which students practice leadership within the respective learning groups. The findings were similar to those of Keiler (2018) in the USA who revealed that LCA helped teachers to develop shared responsibility for students learning with student leaders.

In the observation, the researcher found that in the management of the teaching and learning process where LCA was applied students were able to organize themselves in representing what they learned. This showed that LCA helped students practice leadership when at school and later they might become great leaders in society.

\subsection{Perception of Teachers on the Application of LCA in Teaching and Learning Process}

In this section, the researcher intended to seek the perception of teachers on the use of the Learner-Centered Approach in public secondary schools in the Nyamagana District. The study involved teachers, students, heads of schools, WEOs, and District Education Officers for secondary schools. The researcher used questionnaires to collect data from teachers and students. Furthermore, interview guides were used to collate data from heads of schools, WEOs, and DEO for secondary schools.

\section{Teachers Perception on LCA}

Participants from students were asked whether they enjoyed learning through the Learner-Centered Approach. The finding showed that 85.5 percent responded "Yes" while 14.5 said "No" as shown in figure 7.1. 


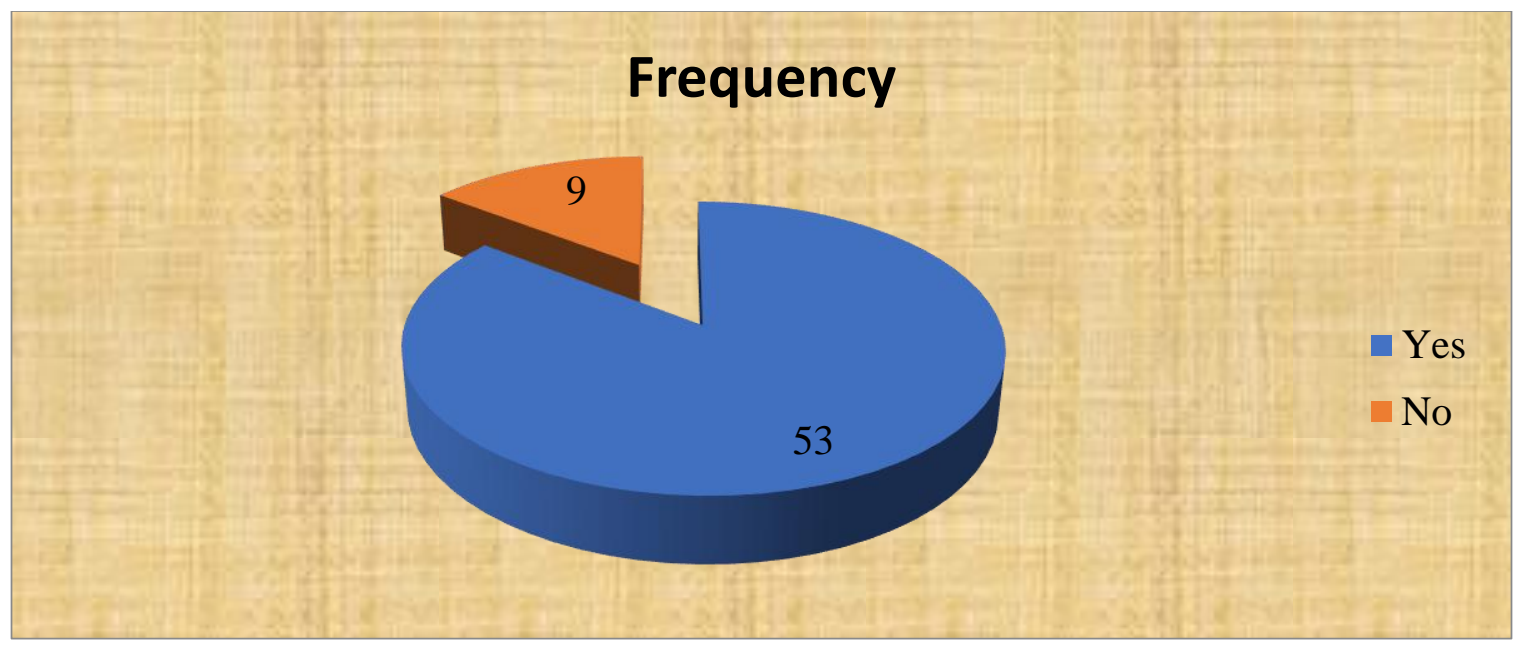

Fig.7.1 Teachers' Response on Enjoying LCA ( $n=62)$

Source: Field Data September 2021

From the findings, the result showed that teachers had good attitudes towards the application of LCA to instruct secondary school students in the Nyamagana district. Despite their positive perception of the use of LCA in teaching students, through observation, the researcher recognized that teachers rarely apply it in teaching students. For example, in the four selected schools, teachers were teaching by lecturing and asking students questions. It should be remembered that students learn best by doing and practicing rather than listening and memorization of facts. The findings were similar to Jony (2016) who found that teachers perceive student-centered instructions as important to improve the ability of students to learn the content and prepare them for class. Although teachers perceive LCA as important teaching and learning method in the selected secondary schools in Nyamagana it was found out that some teachers did not have a clear understanding of LCA, as a result, they only focus on questions and answers. This teaching technique could not develop students' knowledge rather than memorizing facts.

Likewise, participants from students were asked if they enjoyed it when teachers applied LCA in teaching and learning. Figure 7.1 demonstrated that 84.6 replied "Yes" which means that they enjoyed the method while 15.4 percent never enjoyed it.

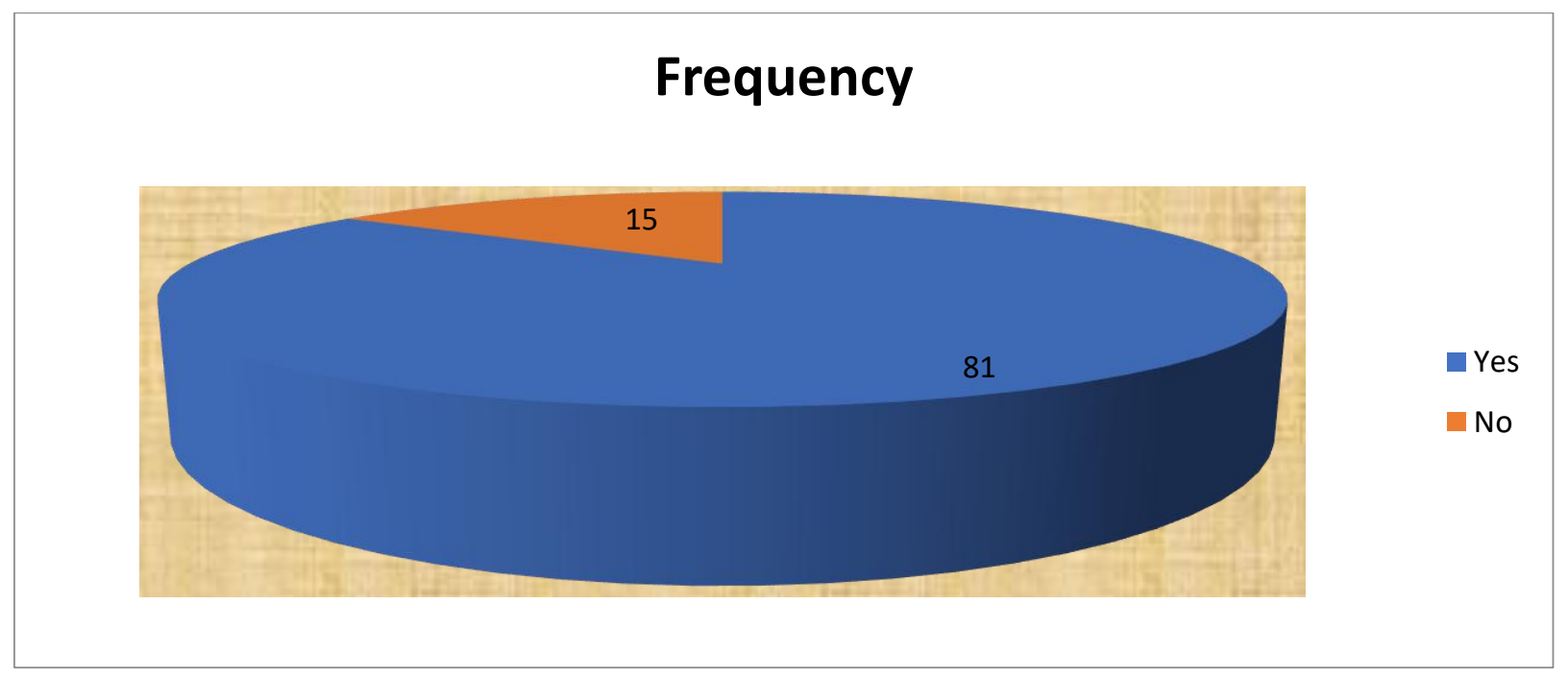

Fig.7.2: Students Responses on Enjoying LCAA

Source: Field Data September 2021 
The finding in figure 4.2 implies that participants had a good perception of the use of LCA in the teaching and learning process however, in the selected schools it was rarely used. Participants viewed LCA as an important teaching and learning technique that develops critical thinking and lifelong life learning skills. Also, the finding shows that 15.6 percent who replied "No" were not aware of the use of LCA in the selected schools. Thus, from the finding, it can be concluded that teachers should emphasize the use of LCA in teaching and learning to boost students' academic performance.

Notwithstanding participants were asked to explain how they perceived the adoption of LCA in teaching and learning. The respondents argued that LCA prepares students for life, develops lifelong learning, learns from students' experience, and develops a sense of confidence, inadequate knowledge as shown in figure 7.3.

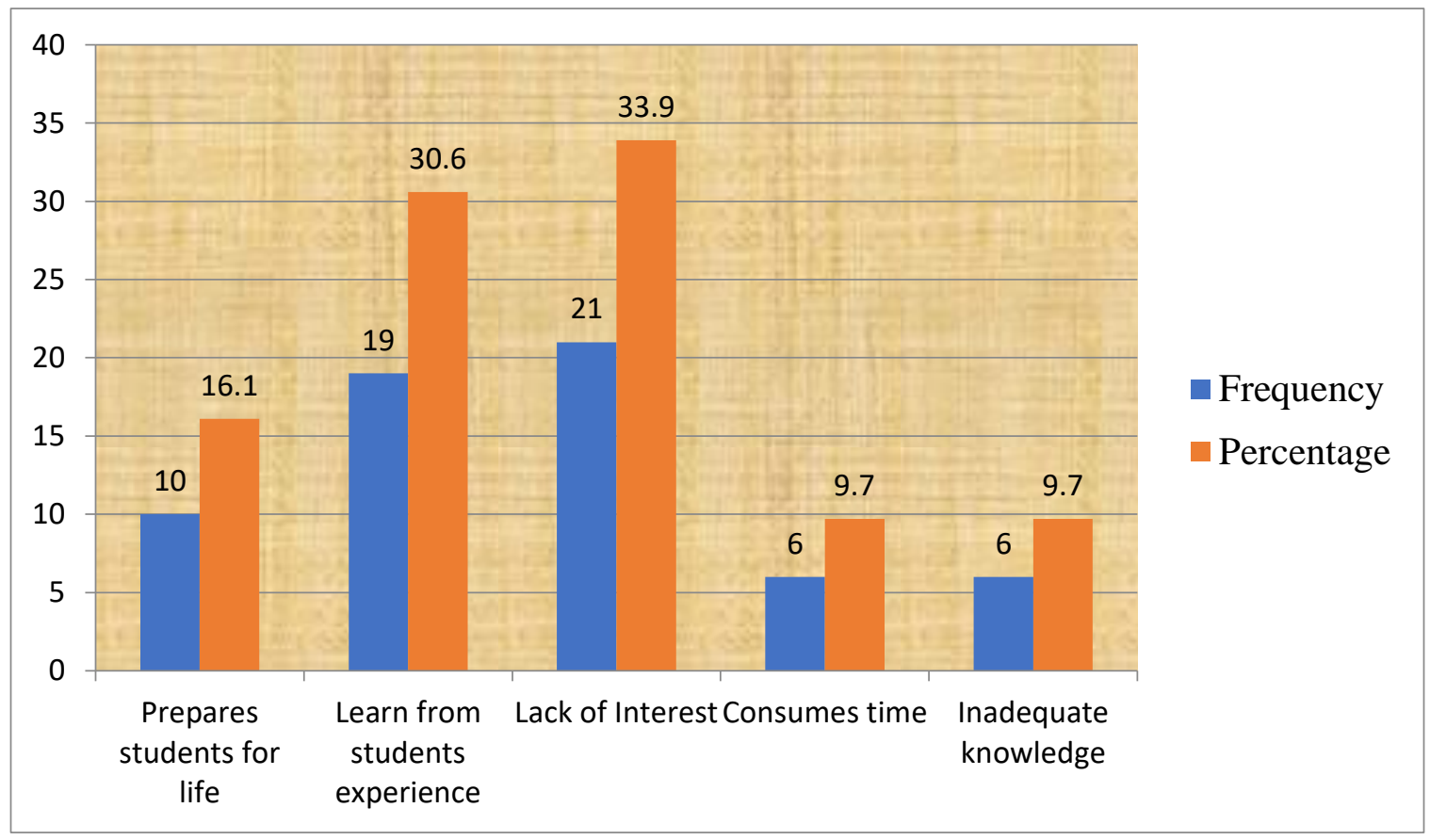

Fig.7.3 Teachers' Perception on LCA $(n=62)$

Source: Field Data September 2021

\section{Prepares students for life}

When teachers were asked to explain how teachers perceived LCA, they indicated that 16.1 percent argued Learner Centred Approach prepared students for life. Likewise, in the interview, a respondent argued:

Teachers have good attitudes towards the Application of LCA in secondary schools. For example, teachers believe that schools in which students participated in different economic activities like gardening, animal keeping, and other economic activities, prepare students for life. But the problem is that current examination pressures hinder the applicability of competency-based education (Interviewee One September 2021).
The findings indicated that teachers had good attitudes on the application of LCA in the teaching and learning process. However, in the real situation, it was rarely practiced in the selected schools in the Nyamagana district. The finding was in line with Jony (2016) in Bangladesh who found that teachers perceived student-centered instructions as important to improve the ability of students to learn the content and prepare them for class. Also, it entailed that LCA was affected by examination pressures whereby teachers did their teaching to make students pass their exams. Moreover, in discussing constructivism learning theory, Neill and McMahon (2005) argued that in constructivism much focus is given to individual learners. However, teachers' and learners' belief system affected their applications. Thus, there is a need to emphasize the application of LCA in the 
teaching and learning process in public secondary schools in the Nyamagana district rather than preparing students for examination.

\section{Learn from students' experiences}

Also, figure 7.3 shows that 30.6 percent of the participants perceived LCA as an important teaching and learning method that could help teachers learn from students' experiences in the study content. The findings entail that participants had positive perceptions of the use of LCA for the teaching and learning process. This is because LCA provides an opportunity for the teachers to learn from students' experiences. Although teachers perceived the use of LCA positively in the teaching-learning process, in the selected schools' teachers did not apply it to the students. The situation made students remain passive in class during the teaching and learning process.

\section{Lack of interest}

Some participants argued that sometimes teachers did not have an interest in the use of LCA in the teaching and learning process. The data in figure 7.3 demonstrated that 33.9 percent said teachers lack interest in the use of LCA to instruct students. The finding was similar to Nyimbili, Namuyamba, and Chakanika, (2018) in Zambia who found that teachers were not interested in teaching using learnercentered techniques hence they use a limited number of teaching activities in the teaching of students in secondary schools.

\section{In the interview, an interviewee asserted,}

However, the government emphasized teachers to apply Learner Centred Approach in the teaching and learning process, still, teachers did not have adequate knowledge of its applications. Teachers normally used question and answers as an LCA teaching technique while other methods were not used. Teachers lacked knowledge and skills on the application of LCA in secondary schools.

Nevertheless, in the observation, the researcher observed that some selected schools had computers but students were not instructed to use computers in the learning process. The finding implies that teachers in the selected schools did not have adequate knowledge of LCA. The situation made teachers lack interest in its application in the teaching and learning process.

In the background to the study, the data showed that the government is insisted on the use of LCA in the implementation of ordinary level secondary education (TIE, 2013). Likewise, the curriculum emphasizes learning to make sense in the life of students and promotes the intended skills and competencies. The findings are also supported by (the MoEC) report which showed that teaching and learning in secondary schools have remained traditional for a long time, most of the teachers have not been exposed to modern teaching and learning practice consistently with current theoretical development in teaching and learning (URT, 2004).

Thus, the findings entailed that teachers in the selected public secondary schools in Nyamagana District have an interest in LCA implementation but do not have adequate knowledge of its application. Therefore, there should be efforts to make sure teachers are well trained on LCA to increase their interest in its application.

\section{Consumes time}

Also, figure 7.3 indicates that 9.7 percent of the participants viewed LCA to consume time in its application. Participants argued that LCA requires adequate time and appropriate class size to enable its application. The finding implied that the majority of the selected secondary schools in the selected field of study had big class sizes which forbade teachers to use LCA in the teaching and learning process. This situation made teachers have negative attitudes towards the application of LCA in the selected schools in the Nyamagana district. The findings were in line with Neill and McMahon (2005) who identified that in constructivism much focus is given to individual learners. However, teachers' and learners' belief system affect their applications. Therefore, some participants had a negative view on the use of LCA in the big class size, which set back its implementation to promote lifelong learning.

\section{Inadequate knowledge}

Inadequate knowledge was explained by the participants by 9.7 percent. Participants argued that teachers did not have adequate knowledge to implement LCA in public secondary schools. Participants viewed inadequate knowledge as the major hindrance to applying LCA in the selected public schools in the Nyamagana district. The finding was similar to Thomas, (2013) who found that teachers in Pakistan were not well equipped with the knowledge and skills required to utilize LCA in class. Therefore, lack of pedagogical content knowledge and beliefs in some teaching methods inhibits them from adopting constructivist student-centered teaching. The findings implied that however, teachers perceive LCA positively in teaching and learning, they do not have adequate knowledge of its application. The situation prohibits the implementation of LCA and thus lowers 
students' academic achievement in the selected public secondary schools in Nyamagana District. Also, the findings were contrary to those of Jabbour (2013) who found that schools required the adaptation of the traditional lecture approach of education through which physical, human and financial resources can be controlled.
Moreover, the study sought to seek the perception of students on implementation of Learner Centred Approach in public secondary schools in Nyamagana in District. Participants were asked to state whether they enjoyed learning through learner-centered pedagogy. The data showed that 84.4 percent said they enjoy the lesson while 15.6 percent denied as indicated in figure 4.4.

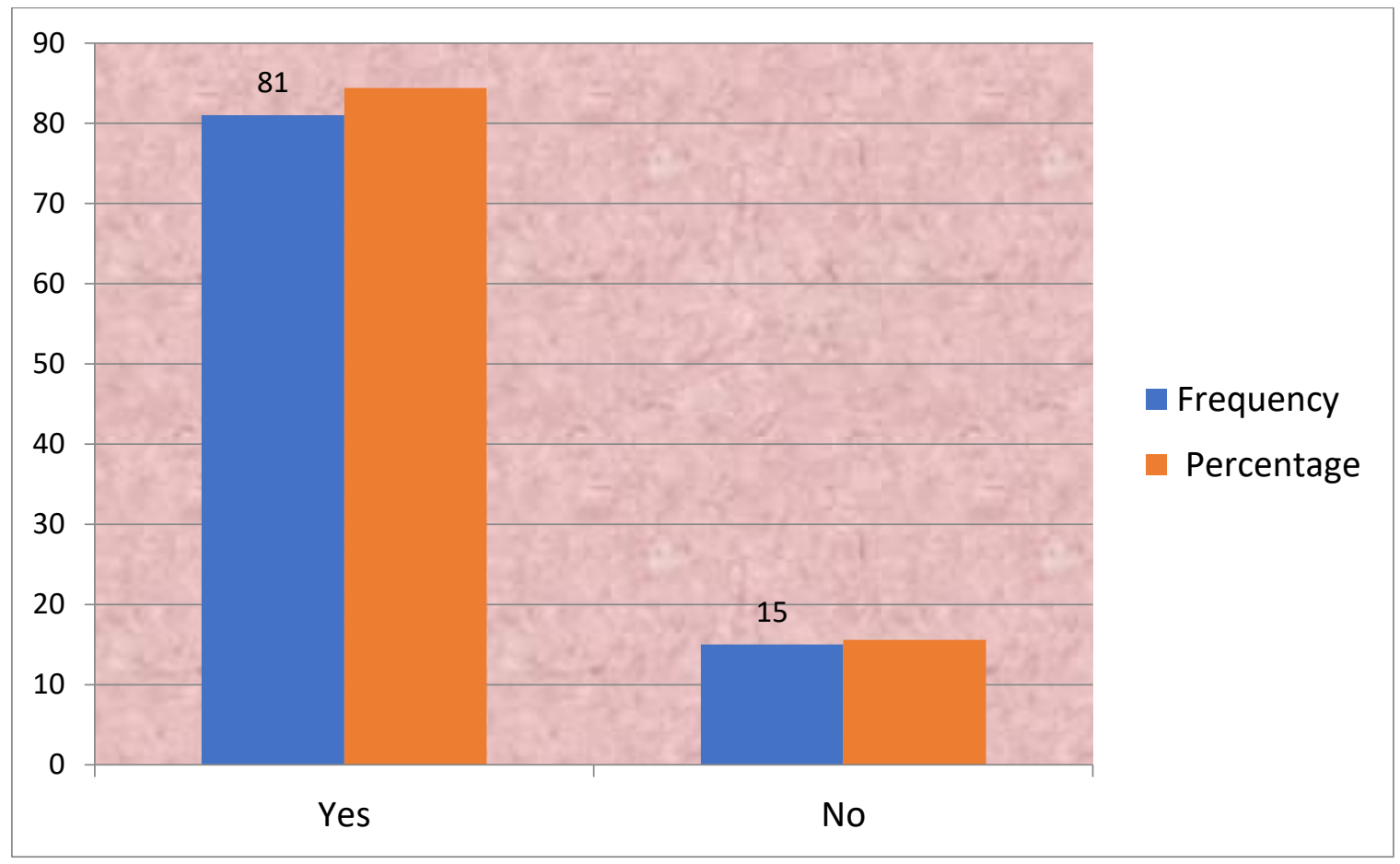

Fig.7.4 Students Perceptions on LCA

Source: Field Data September 2021

From the findings, it was indicated that participants had a good perception of the use of LCA in the learning process. The finding showed that participants enjoyed learning through LCA because it stimulated their thinking capacity and develops lifelong learning skills. However, in the selected public secondary schools LCA was rarely applicable. During the interview, an interviewee asserted,

Our students preferred practical learning like field trips but sometimes financial deficits made us have limited field trips in schools. Some parents do not want even to support their children financially when fields trip is demanded by students. This situation forbids the implementation of LCA in school (Interviewee $5^{\text {th }}$ September 2021).

The finding implies that students were eager on pedagogical content which focused on LCA but its application in school is minimal.

On the other hand, participants were asked to explain how they perceive LCA application in schools. The participants explained that LCA is important pedagogical content that develops lifelong learning skills, develops confidence in students, and consumes time in its application as shown in figure 7.5. 


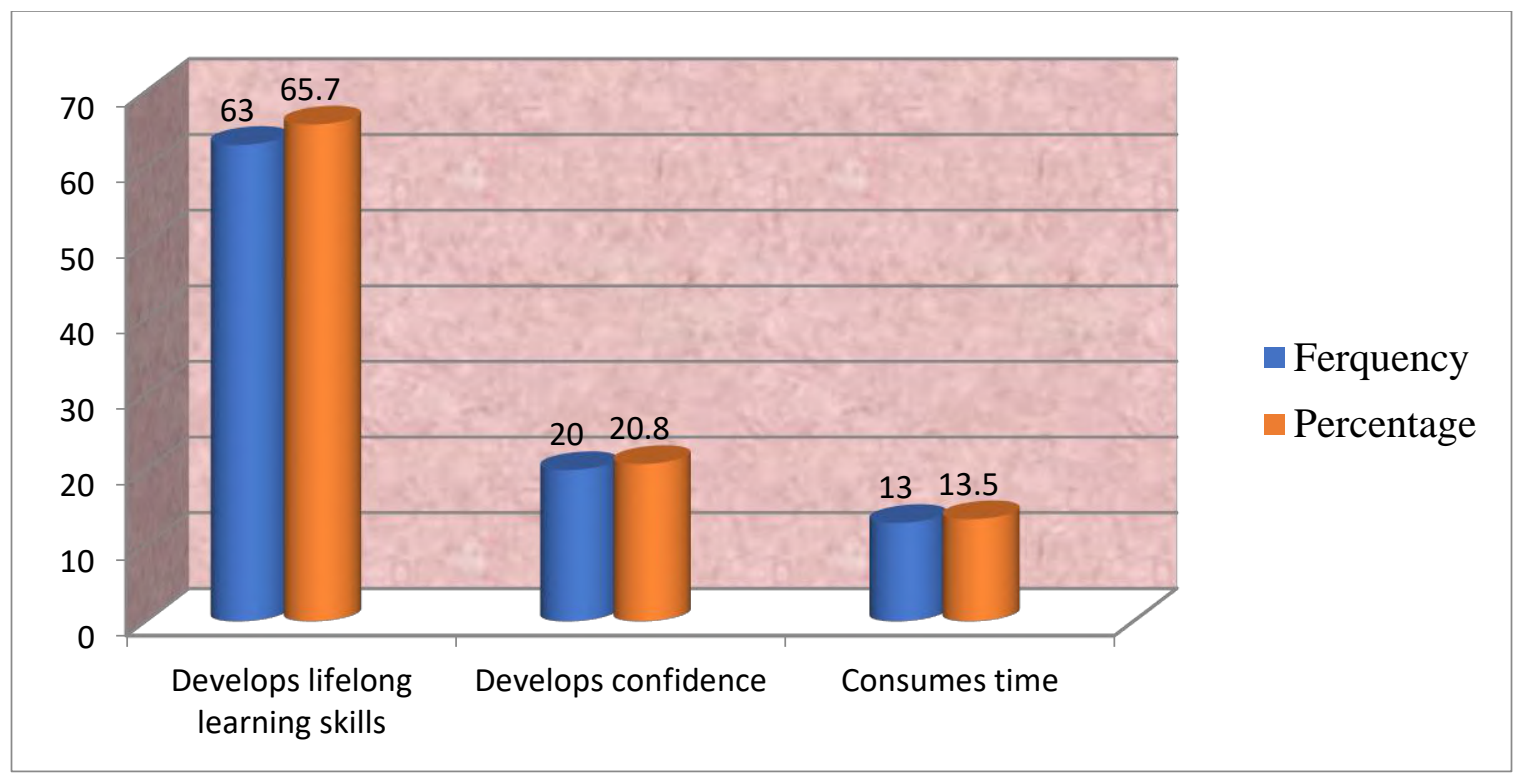

Fig.7.5: Students Perception in Adoption of LCA

Source: Field Data September 2021

Figure 7.5 indicated that 65.7 percent argued that adoption of LCA helped students to develop lifelong learning skills. The finding implied that the majority of the participants had positive attitudes towards the application of LCA. Participants explain that when student-centered is implemented it develops creativity, innovations, and curiosity in students. The findings were similar to Kok and Lim (2016) in Malaysia who found that teachers viewed LCA as an important learning approach in which students engaged in the learning process, be aware of their responsibilities, create a sense of autonomy in learning, and teachers can learn from their experience. Notwithstanding, in discussing principles of Constructivism learning theory Dagar (2016) maintained that learning should stimulate students thinking activities and enhance their meta-cognitive and self-regulative skills which are embedded in the study content knowledge. Therefore, although both teachers and students had positive perceptions on the use of LCA on developing lifelong learning skills in students, in the selected secondary schools were either implemented partially or not implemented at all. There is a need to emphasize the application of LCA in the selected schools in the Nyamagana District.

\section{Developing students' confidence}

Also, figure 7.5 demonstratedthat the adoption of the Learner Centred Approach develops students' confidence by 20.8 percent. Participants explained that when LCA was used in the teaching and learning process, students developed confidence in various matters. For example, a student who works in collaboration exercises leadership at schools and develops independent learning. In constructivism learning theory, Museum and Israel (1991) argued that learners construct knowledge for themselves and each learner individually and socially constructs meaning as he or she learns. Therefore, LCA helps students to be confident and develops independent learning. In the selected secondary schools, the researcher found out that where LCA was practiced students were confident to ask and learn more for what was taught compared to schools where teacher-centered was mostly implemented.

\section{Consuming Time}

Also, figure 7.5 showed that 13.5 percent said the adoption of LCA in the teaching and learning process consumes time. Participants argued that teachers who advocated LCA as a teaching pedagogy require abundant time for preparation and in the teaching process. The finding was in line with Jabbour (2013) that schools require the adaptation of the traditional lecture approach of education through which physical, human and financial resources can be controlled. The finding implied that students believed that LCA needs time and conducive teaching and learning environment which supports the adoption of LCA. For example, for schools where there are big class sizes, teachers consume time, especially when opting to apply a student-centered approach 
in the teaching and learning process. Participants argued that teachers consume much time in assigning students in groups for discussion and presentation of their work. The finding also implied that the application of LCA requires an appropriate class size for a teacher to manage the approach. Thus, however, students perceived the approach positively; they showed that it may consume time in the absence of good class size.

\section{CONCLUSION AND RECOMMENDATIONS}

\subsection{Conclusion}

This study sought to ascertain the implementation of Learner Centred Approach to reposition education in public secondary schools. Based on the findings the study concludes that Learner Centred Approach plays a significant in students learning outcomes. The findings showed that LCA develops critical thinking, problem-solving skills, cooperation, and career choice skills in students. However, the findings indicated LCA as an important learning approach that develops lifelong learning for the students, teachers had varied perceptions towards the implementation of LCA. Some teachers believed that the learner-centered approach prepares the student for life while others believed that teachers do not have adequate knowledge to implement a student-centered approach. Moreover, participants argued that LCA requires adequate time for its usage.

\subsection{Recommendations}

Based on the study findings, the researcher recommended the following for effective implementation of Learner Centred Approach in public secondary schools.

i. The government enacts effective education and training policy to emphasize the implementation of a student-centered approach in public secondary schools. The policy should be enforced by strict laws to ensure its implementation.

ii. Notwithstanding, the Ministry of Education Science technology should plan for training and retraining for teachers on the adoption of the new teaching paradigm to equip teachers with the required knowledge for the application of LCA.

\section{REFERENCES}

[1] Asoodeh, M. H., Asoodeh, M. B., \&Zarepour, M. (2012). The impact of student-centered on academic learning achievement and social skills. Procedia-Social and Behavioural Science, 46, 560-564. https://doi.org/10.1016/j.sbspro.2012.05.160
[2] Benlahcene, A., Lashari, S., Lashari, T., \& Shehzad, W. (2020). Exploring the perception of students using studentcentered learning approach in a Malaysian public university International journal of higher education. vol. 9, 1(January). https://doi.org/ 10.5430/ijhe.v9n1p204

[3] Businge, D., \&Kakongoro, K. (n.d.). The teacher-centered delivery approach in Uganda's secondary school education and empowering learners with higher-order skills. Unpublished Dissertation, 99-116. https://doi.org/10.4018/978-1-5225-6331-0.ch007

[4] Cabe, A. M. (2015). Tourism and hospitality research in Ireland conference Cork institute of technology 2014 studentcentred learning: ' Letting Go ', the role and responsibility of the lecturer. (May 2014).

[5] Cain, C. M. (2020). Understanding the Use of LearnerCentered Teaching Strategies by Secondary Educators at Walden University. Unpublished Dissertation.

[6] Ching, L. F., Lawrence, R., \& Abdullah, H. (2019). Studentcentred learning in a selected higher education institution. International Journal of Innovative Technology and Exploring Engineering (IJITEE), (2), 505-510. https://doi.org/10.35940/ijitee. B1121.1292S319

[7] Cresswell, J. \& Plano, C. V. (2007). Designing and conducting mixed methods research. Thousand Oaks, CA: Sage.

[8] Dagar, V. (2016). Constructivism : a paradigm for teaching and learning constructivism: A Paradigm for Teaching and Learning. (January). https://doi.org/10.4172/21516200.1000200

[9] Ec, E. (2020). Student teachers ' perceptions, experiences, and challenges regarding learner-centred teaching. South African Journal of Education, 40(1), 1-10.

[10] Garrett, T. (2008). Student-centred and teacher-centred classroom management: A case study of three elementary teachers. The Journal of Classroom Interaction, 34-47.

[11] Gelisli, Y. (2009). The effect of student-centred instructional approaches on student success. Journal of Procedia Social and Behavioural Science, $\quad 1, \quad 469-473$. https://doi.org/10.1016/j.sbspro.2009.01.085

[12] Go, A., Krawczak, M., \&Pawe, G. (2018). Empowering teachers for a student-centred approach. Unpublished Dissertation.

[13] Gunduz, N., \&Hursen, C. (2015). Constructivism in teaching and learning; content analysis evaluation. Procedia - Social and Behavioural Sciences, 191(392), 526-533. https://doi.org/10.1016/j.sbspro.2015.04.640

[14] Harriss, J. and Spina, N. (2013). Literature review : Studentcentred schools make a difference. Brisbane Australia: Queensland University of Technology.

[15] Iddy, S., \&Chiwanga, F. E. (2017). Is the learner-centred approach indeed adopted in the teaching-learning of French in O-level state secondary schools in Dar es Salaam, Tanzania? Educational Research Journal, 7 (June), 123-133. 
[16] Jabbour, K. K. (2013). Issues that restrain teachers from adapting student-centred instruction in Lebanese school. Unpublished Dissertation, 17, 85-96.

[17] Kamugisha, N. A. (2019). The use of learner-centred approach and materials in teaching and learning social science subjects in Tanzania secondary schools. 3(8), 84-93.

[18] Keiler, L. S. (2018). Teachers' roles and identities in studentcentred classrooms. International journal of STEM education, 5(1), 1-20.

[19] Kok, E., \& Lim, S. (2016). Investigating teachers ' views of student-centred learning approach investigating teachers ' views of student-centred learning approach. International Education Studies, Vol.7 (7). (September). https://doi.org/ 10.5539/ies.v7n7p143

[20] Kumar, M. K. (2016). Challenges of implementing studentcentred strategies in classrooms. International Research Journal of Engineering and Technology (IRJET), 3(12), 12241227.

[21] Manqele, C. M. (2017). An evaluation of learner-centred teaching as part of curriculum delivery in under-resourced schools. Unpublished Doctoral Thesis, University of South Africa.

[22] Matsau, M. A. (2007). Investigating the learner-centred approach in language teaching in Lesotho. Unpublished Dissertation.

[23] Mtitu, E. A. (2014). Learner-centred teaching in Tanzania: geography teachers ' perceptions and experiences: A thesis submitted to Victoria University of Wellington in fulfilment of the requirements for the degree of Doctor of Philosophy Victoria University. Unpublished Doctoral Thesis, Victoria University of Wellington.

[24] Museum, T., \& Israel, J. (1991). Constructivist learning theory (pp. 15-22). pp. 15-22.

[25] Neill, G. O., \& McMahon, T. (2005). Student-centred learning: What for students and lecturers? What does it mean? University College Dublin.

[26] Ngailo, M. (2019). Investigate the perceptions of teachers and students on the implementation of field trip in enhancing learner-centred approach in Tanzanian secondary schools: A case study of Mbeya city master of arts in education at the University of Dodoma. Unpublished Dissertation, University of Dodoma.

[27] Nyimbiri, F. (2016). The use of Learner Centred Techniques in the teaching of English language in selected secondary schools of Lundazi district. Unpublished Master's Dissertation, University of Zambia.

[28] McKean, S. (2014). The Effects of Implementing Studentcentred Learning on At-risk Students' Self-efficacy (Doctoral dissertation).

[29] Singh, N. (2011). Student-centred learning (SCL) in classrooms - A comprehensive overview. Educational Quest, 2(2), 275-282.

[30] Jony, S. (2016). Student centred instruction for interactive and effective teaching learning: Perceptions of teachers in
Bangladesh. International Journal of Advanced Research in Education \& Technology (IJARET), 3(3), 172-178.

[31] Thomas, M. (2013). Teachers ' beliefs about classroom teaching - teachers ' knowledge and teaching approaches. Procedia - Social and Behavioural Sciences, 89, 31-39. https://doi.org/10.1016/j.sbspro.2013.08.805

[32] TIE. (2013). Curriculum for ordinary level secondary education (p. 40). Ministry of Education Science and Technology. Dar es Salaam Tanzania. https://doi.org/10.1017/ CBO9781107415324.004

[33] Toole, L. O. (2015). Student-centred teaching in initial teacher education. International Journal for Cross-Disciplinary Subjects in Education (IJCDSE), 6(1), 2111-2119.

[34] URT. (1999). Tanzania development vision 2025. Ministry of Education and Culture. Dares-Salaam Tanzania.

[35] URT. (2004) Education sector development programme: a mechanism for posting teachers to government secondary schools for ESDP 2004-2009. Ministry of Education and Culture Dares-Salaam- Tanzania.

[36] URT. (1999). Secondary education master plan (SEMP). Ministry of Education and Culture (MoEC). Dares-Salaam Tanzania.

[37] URT. (2004). Secondary education development programme (SEDP). Ministry of Education and Culture. Dares-Salaam Tanzania.

[38] Zek, C. P. (2014). Student teachers ' perceptions about their experiences in a student-centred course. South African Journal of Education, 34(3).

[39] Zhao, W., Ah, I., \&Mok, C. (2019). Factors influencing teachers ' implementation of a reformed instructional model in China from the theory of planned behaviour perspective: A multiple case study. Journal ofSustainability, 12(1), 1-21. 